\title{
Chicken (Gallus gallus domesticus L.) Cuts Yield Specifics of Cobb 500 Slow and Hubbard Flex Hybrids
}

\author{
Soares C. E. ${ }^{1, *}$, Dahlke F. ${ }^{2}$, Netto D. P. ${ }^{2}$, Scussel V. M. ${ }^{1}$ \\ ${ }^{1}$ Food Science and Technology Department, Center for Agricultural Sciences, Federal University of Santa Catarina, Florianopolis, Brazil \\ ${ }^{2}$ Rural Development and Zootechny Department, Center for Agricultural Sciences, Federal University of Santa Catarina, Florianopolis, \\ Brazil
}

\begin{abstract}
Chicken (Gallus gallus domesticus L.) cuts yield of wing (drummette / middle joint / tip), breast (fillet / tenderloin) and leg (drumstick / thigh / feet) of two specific hybrids (Cobb 500 Slow - CB-Slow and Hubbard Flex - HB-Flex) were evaluated. A total of 150 birds of each hybrid (grown in separate sheds under same management) were utilized for the study. The trials were carried out under randomly design with 24 replicated for each lineage. From the data obtained it was observed that the cuts yield of CB-Slow birds was higher for breast when compared to HB-Flex. On the other hand, the HB-Flex birds had higher cut yields for leg (drumstick - meat \& bone) and wing (drummette / middle joint / tip). Yields for tenderloin, breast bone and upper drumstick (meat) both hybrids did not show significant differences. The knowledge of specific chicken hybrid cuts differences, enables more accurate choices that best fits the consumer's market needs.
\end{abstract}

Keywords Chicken, Carcass, Cuts, Gallus gallus domesticus, Yield

\section{Introduction}

Chicken meat (Gallus gallus domesticus L.) is considered an excellent source of protein and a low caloric food, providing only $10 \%$ of the daily need. A breast fillet portion $(100 \mathrm{~g})$ provides $30 \mathrm{~g}$ of protein, on the other hand, thigh and drumstick $20 \mathrm{~g}$. It is also a source of minerals (selenium, phosphorus, zinc, iron, potassium and magnesium) and vitamins of B complex (B1, B2, B6, B12 and pantothenic acid), as well as of $\mathrm{A}, \mathrm{C}$ and $\mathrm{K}$ (present in edible viscera liver/gizzard/heart) [1-3].

The growth speed of birds, has a directly influence on the carcass yield and cuts, which makes chicken an important piece for economic return [4]. The first Brazilian chicken cuts export ocurred in the early 80 's, which led the industries to expand their slaughtering capacities and implement the automated production lines. That period marked also a change on chicken meat consumption habit in the country. These changes in the habit of consuming poultry meat also happen in other continents. Prior that, industries only produced and sold whole chicken $[3,5]$.

To reach consumers market needs, it is essential to keep updating the birds production characteristics (birth weight / mother age / slaughtering age \& weight / average batch weight/ yield \& each cuts weight). Therefore, to evaluate the

* Corresponding author:

cesszootec@gmail.com (Soares C. E.)

Published online at http://journal.sapub.org/fph

Copyright (C) 2017 Scientific \& Academic Publishing. All Rights Reserved differences between cuttings among chicken, knowledge on hybrids specifics is essential. They provide information on production features to meet the consumer market demand [6, 7]. The animal's carcass quality is determined primarily by its yield of meat / bone / fat.

It is worth emphasizing that chicken cuts specifics have been the consumers increasing demand, mainly by their food habit changes on, either of (a) special cuts and/or (b) boneless products consumption. The increasing habits of easy cuts for fast preparations $[1,8,9]$.

As the birds become heavier due to their genetic enhancement and nutrition, it is expected also their yields improvement. Thus, meat companies that commercialize carcasses (whole or cuts) can better choose the exact hybrid to reach their needs.

Several hybrids (Cobb, Hubbard, Ross, Paraíso Pedres, Isa Label, Arbor Acres and Avian Farms), are already in the market and their yield in different cuts have been compared and reported in the literature with different characteristics registered specifically among wings, breast and legs. However, there is a lack of information on specific characteristics among each lineage [10, 11, 3, 12, 9, 13-15].

Considering the need for more accurate and specific ratings of the commercial lineages (Cobb and Hubbard), this study investigated the hybrids Cobb500 Slow (CB-Slow) and Hubbard Flex (HB-Flex) utilized in the Southern Brazil chicken production chains for different cuts (wing/breast/leg and yield) from hot carcasses (i.e., prior passing through chillers). 


\section{Materials and Methods}

1. Animals: 300 chicken (males), 42 days old, from two hybrid specific lineages (Slow-CB and HB-Flex). They were grown in 2 different sheds, separated by lineage (150 birds each). All the birds handling was performed by a single producer under same conditions according to technical material of the cooperative.

2. Chicken capture and preparation: when fully grown and ready for slaughtering, chickens were captured randomly, separated by their respective hybrids, weighted (hanging scale, Veit Electronics), identified by a numbered seal on both legs (Figure 1.a) and sent to the slaughtering house (after $8 \mathrm{~h}$ fasting) according to the National Ministry of Agriculture regulation procedure [16].

3. Slaughtering: chicken were previously (a) weighed by means of a hanging scale, then sent for (b) slaughtering - through stunning, bleeding and evisceration (birds with injuries/missing parts were discarded); followed by (c) carcasses sample collection - 24 units of each lineage were separated (prior passing through chiller) and their seals checked (Figure 1.b) for further cuts identification.

4. Cuts preparation and deboning:

(a) cuts preparation - the carcass parts were separated according to the different cuts Types as follows. GROUP I: wings (drummette/middle joint/tip) GROUP II: breast (filet / tenderloin *) GROUP III: legs (drumstick / thigh / feet)

(b) deboning - drumstick and thighs had their bones separated, including skin and fat GROUP IV: drumstick \& bones/ thigh \& bones/back bone - deboning (Figure 2)
All procedure was carried out by the same operator using stainless steel knives. Cuts and seals (from each bird) were kept together in the same tray (expanded polystyrene) for the next step - weight. [* inside breast fillet]

(c) weighing - each item (cuts, sub-cuts and deboning) obtained in (a) and (b) was weighed (scale, model 2090, Toledo) for yield calculation.

5. Cuts weight and yield versus whole carcass: from birds data obtained at the (a) slaughtering house (before conveyor hanging and after slaughtering whole, clean carcass) and the (b) cuts obtained; the weight and yield Tests were applied (for the cuts GROUPS: I, II, III and IV) as follows.

WEIGHT TEST: with all cuts weighed, the 2 hybrids, had calculated their proportions (meat / bone / skin) versus each carcass, following features of their proper GROUPS I, II, III and IV. Those data were applied next, to calculate the yield percentage.

YIELD TEST: was carry out for the 2 chicken cuts hybrids main GROUPS, as well as carcass, i.e, (a) per unity (cut) and (b) total (carcass) - weight prior slaughtering (live and after fasting). The following equations were applied:

[a] individual yield (\%) = slaughter weight $x 100 /$ cutting weight

[b] total yield $(\%)=$ sum of cuts $x 100 /$ slaughter weight.

Note: it is important to emphasize that it was not possible to establish the age of the broiler breeders (eggs) and chicken weight (chicks), also, for the age of the mothers (eggs) and birth weight (chicks).

6. Statistical analysis: it was applied ANOVA (SAS, version 9.1) and the averages compared by Tukey test $(\mathrm{P}<0.05)$ to evaluate the significant differences.
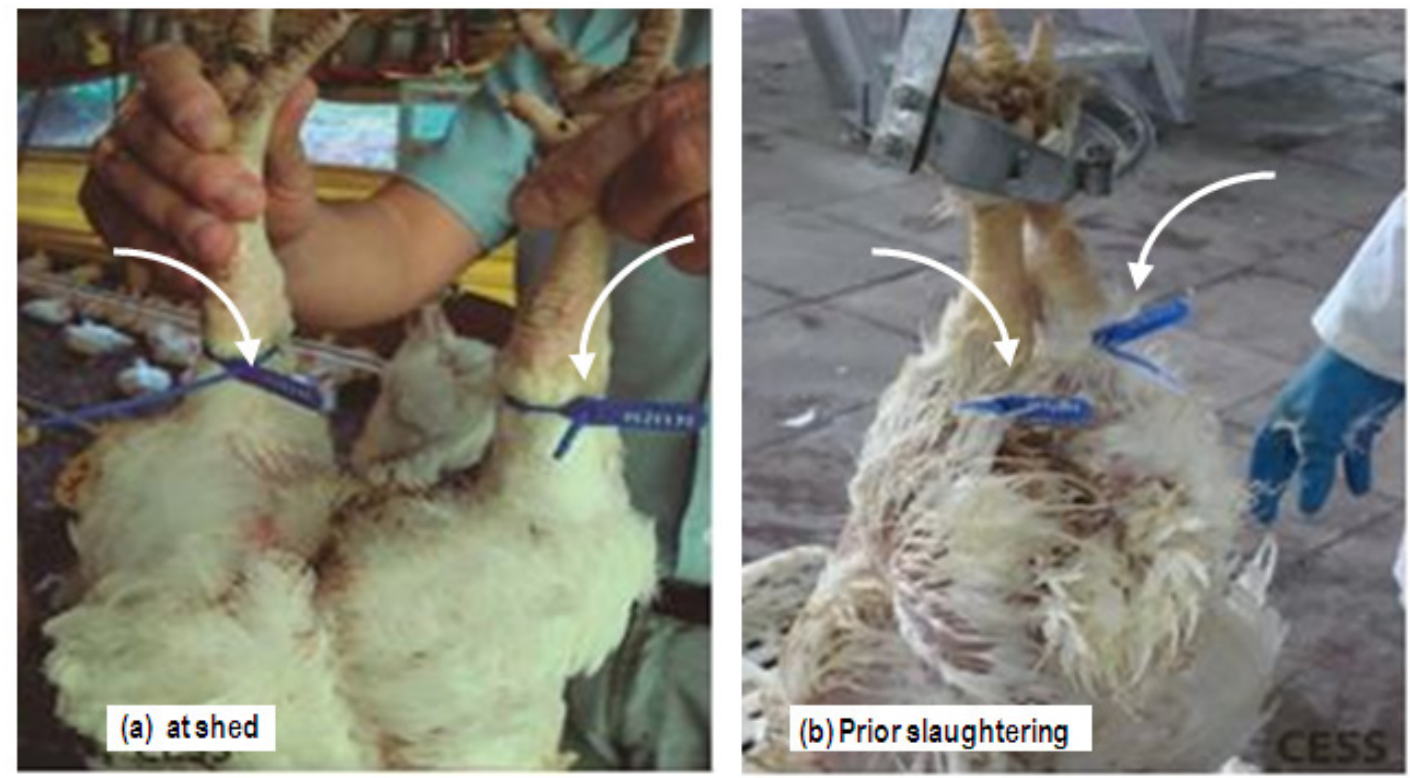

Figure 1. Chicken (Gallus gallus domesticus L.) seal identification for tracking individual custs at (a) shed and (b) prior slaughtering 

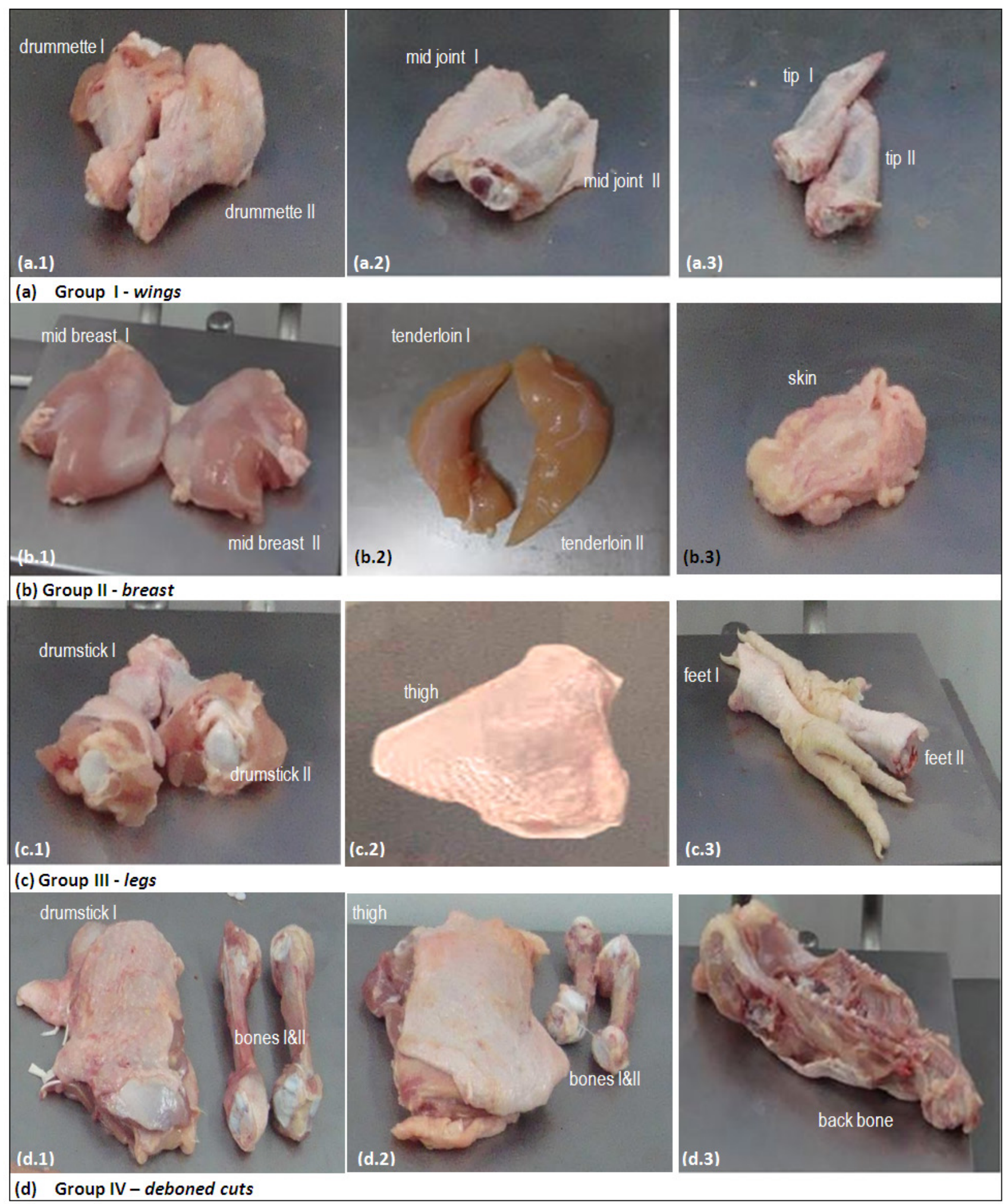

\section{(d) Group IV-deboned cuts}

Figure 2. Chicken (Gallus gallus domesticus L.) cuts from Groups (a) I -wing; (b) II -breast; (c) III - leg and (d) IV - deboned cuts

\section{Results and Discussion}

From the data obtained, some differences were observed for both, weight and yield of chicken cuts of the two specific hybrids (CB-Slow and HB-Flex) evaluated in the study. The main cuts that stood in yield were breast (fillet \& skin) and drumstick / thighs / wings, for the CB-Slow and HB-Flex lineages, respectively. Table below shows the weight and yield data of the chicken cuts GROUPS I, II, III and IV. 
Chicken cuts from Cobb 500 Slow and Hubbard Flex hybrids - weight and yield

\begin{tabular}{|c|c|c|c|c|c|c|c|c|}
\hline \multirow{3}{*}{$\begin{array}{c}\begin{array}{c}\text { POULTRY } \\
\text { CUTS }^{1}\end{array} \\
\text { Group }\end{array}$} & \multicolumn{6}{|c|}{ COMMERCIAL HYBRID } & \multirow{3}{*}{ RSD $\%{ }^{4}$} & \multirow{3}{*}{$\mathbf{P}^{5}$} \\
\hline & \multicolumn{4}{|c|}{ CB-Slow $^{2}$} & \multicolumn{2}{|c|}{ HB-Flex ${ }^{3}$} & & \\
\hline & \multicolumn{2}{|c|}{ Type } & Average & Range & Average & Range & & \\
\hline \multicolumn{9}{|l|}{ [A] Weight (g) ${ }^{6}$} \\
\hline \multirow[t]{4}{*}{ WING } & Whole & & 190.0 & $\mathrm{NA}^{7}$ & 200.6 & NA & NA & NA \\
\hline & Drummette & & 95.8 & $79-101$ & 101.4 & $84-118$ & 12.75 & 0.1556 \\
\hline & Middle** & & 70.7 & $63-74$ & 73.8 & $64-92$ & 8.82 & 0.1296 \\
\hline & Tip $* * *$ & & $23.5^{\mathrm{b}}$ & $21-25^{\mathrm{a}}$ & $25.4^{\mathrm{a}}$ & $22-30$ & 8.42 & 0.0070 \\
\hline \multirow[t]{5}{*}{ BREAST } & Whole & & 734.8 & NA & 630.3 & NA & NA & NA \\
\hline & Fillet & & $452.0^{\mathrm{a}}$ & $360-585$ & $361.0^{b}$ & $284-467$ & 9.39 & 0.0001 \\
\hline & skin & & $55.4^{\mathrm{a}}$ & $40-67$ & $44.7^{\mathrm{b}}$ & $34-65$ & 14.0 & 0.0002 \\
\hline & bon & & 128.6 & $101-165$ & 131.4 & $102-166$ & 9.84 & 0.6306 \\
\hline & Tenderloin* & & 98.8 & $53-120$ & 93.2 & $63-123$ & 14.1 & 0.2424 \\
\hline \multirow[t]{6}{*}{ LEG } & Drumstick & Whole & 269.5 & NA & 276.4 & NA & NA & NA \\
\hline & & meat & 197.5 & $164-251$ & 198.0 & $161-239$ & 6.78 & 0.9374 \\
\hline & & bone & $72.0^{\mathrm{b}}$ & $57-90$ & $78.4^{\mathrm{a}}$ & $67-89$ & 8.05 & 0.0068 \\
\hline & Thigh & Whole & 349.2 & NA & 336.0 & NA & NA & NA \\
\hline & & meat & 309.5 & $251-362$ & 291.8 & $242-350$ & 6.14 & 0.0664 \\
\hline & & bone & $39.7^{\mathrm{b}}$ & $35-47$ & $44.2^{\mathrm{a}}$ & $39-51$ & 8.87 & 0.0001 \\
\hline FEET & & & $104.8^{\mathrm{b}}$ & $85-123$ & $114.7^{\mathrm{a}}$ & $94-130$ & 7.20 & 0.0026 \\
\hline Others & Backbone & & 310.3 & $270-368$ & 316.3 & $9.9-14.9$ & 8.23 & 0.0427 \\
\hline WHOLE CHICK & $\mathbf{N}^{8}$ after fasting & & 2735.9 & $2345-3110$ & 2655.2 & $2211-3535$ & 8.19 & 0.2438 \\
\hline \multicolumn{9}{|l|}{$[\mathrm{B}]$ Yield $(\%)^{6}$} \\
\hline \multirow[t]{3}{*}{ WING } & Drummette & & $3.58^{\mathrm{b}}$ & $3.1-4.2$ & $3.95^{\mathrm{a}}$ & $3.4-4.8$ & 10.59 & 0.0038 \\
\hline & Middle $^{* *}$ & & $2.65^{\mathrm{b}}$ & $2.3-2.9$ & $2.87^{\mathrm{a}}$ & $2.6-3.1$ & 4.47 & 0.0001 \\
\hline & Tip*** & & $0.88^{\mathrm{b}}$ & $0.8-0.9$ & $0.99^{\mathrm{a}}$ & $0.9-1.1$ & 5.69 & 0.0001 \\
\hline \multirow[t]{4}{*}{ BREAST } & Fillet & & $16.95^{\mathrm{a}}$ & $13.0-20.0$ & $14.00^{\mathrm{b}}$ & $11.8-15.9$ & 9.39 & 0.0001 \\
\hline & & skin & $2.08^{\mathrm{a}}$ & $1.6-2.6$ & $1.73^{\mathrm{b}}$ & $1.3-2.4$ & 14.00 & 0.0002 \\
\hline & & bone & 4.83 & $3.9-5.7$ & 5.11 & $4.2-6.7$ & 9.84 & 0.0689 \\
\hline & Tenderloin* & & 3.70 & $1.9-4.5$ & 3.63 & $2.4-4.2$ & 14.10 & 0.6409 \\
\hline \multirow[t]{4}{*}{ LEG } & Drumstick & meat & $7.40^{\mathrm{b}}$ & $5.9-8.3$ & $7.72^{\mathrm{a}}$ & $6.4-8.9$ & 6.78 & 0.0470 \\
\hline & & bone & $2.70^{\mathrm{b}}$ & $2.4-3.1$ & $3.06^{\mathrm{a}}$ & $2.6-3.5$ & 8.05 & 0.0001 \\
\hline & Thigh & meat & 11.63 & $10.3-13.3$ & 11.36 & $9.7-12.9$ & 6.14 & 0.2375 \\
\hline & & bone & $1.49^{\mathrm{b}}$ & $1.3-1.9$ & $1.72^{\mathrm{a}}$ & $1.4-2.0$ & 8.87 & 0.0001 \\
\hline FEET & & & $3.93^{\mathrm{b}}$ & $3.5-4.6$ & $4.48^{\mathrm{a}}$ & $3.9-5.0$ & 7.20 & 0.0001 \\
\hline Others & Backbone & & $11.65^{\mathrm{b}}$ & $9.70-12.7$ & $12.28^{\mathrm{a}}$ & $9.9-14.9$ & 8.23 & 0.0427 \\
\hline
\end{tabular}

\section{WEIGHT - CUTS \& CARCASS}

(A) CUTS (MEAT X BONE): the cuts are fraction with or without skin / bone and mutilations. For export the wing is marketed as drummette, mid-wing and wing tip. Although the breast is the major focus for the different sectors of the meat industry, the thigh and drumstick are the most consumed products, mainly in the South, Southeast and Midwest regions of Brazil [17]. In the evaluation of this study for cuts, through their average weight (absolute value), it was observed that the HB-Flex hybrid the highest bone weight (both thigh and the drumstick). As shown in the Table above. Even with the highest average drumstick bones weight, the HB-Flex hybrids presented a lower weight of full leg quarters, when compared to CB-Slow. The HB-Flex also presented larger whole thigh (meat and bone) weight. So, in that hybrid, the thigh's bone was responsible for the higher thigh weight. The other breast parts (tenderloin and bone), wings (drummette and middle joint wing) and leg (thigh and 
drumstick), as well as the back, no significant differences were recorded $(\mathrm{P}<0.05)$. In the literature, [14] found best results in breast weight (Group II) only on hybrid CB (at 35 days of age, using 3 different feed composition). On the other hand, for the HB commercial hybrid, the authors reported best weights and yields for legs (thigh and drumstick). In results reported by [12] the authors did not observe a significant difference between those hybrids (for different cuts) because they utilized different parameter $(\mathrm{P}>0.10)$. However if it was observed at $\mathrm{P}<0.05$, significant differences between those cuts would be observed, as reported, only for boneless legs, by the authors. (*Note: the leg drumstick and thigh subdivisions, had their meat considered whole weight, including the skin).

(B) CARCASS: chicken carcass is the product without viscera, usually weighing below $2000 \mathrm{~g}$ for use in the meat products industry (as cuts). Above this weight, it is more used for frozen whole. Some authors describe the carcass: with or without neck, head and viscera edible.

\section{YIELD - CUTS}

(A) INDIVIDUAL: as expected, the average yield of all chicken cuts of the specific hybrids (CB-Solw and HB-Flex) evaluated, presented differences. It was possible to observe that the CB-Slow birds presented a better average yield for Group II, i.e., breast. These data is supported by literature, where authors such as [9, 14, 12], also reported high yields for hybrid CB. On the other, in the present study, the highest yield Groups I - wing (drummette, middle joint and tip) and some of the Group III - legs, i.e., drumstick (whole and bone), thigh bone and feet, as well as other cuts - back, were obtained by birds of the HB-Flex. Flemming and Winkelstroter $[12,14]$ also found high yield of wing and legs for HB. It was considered the yield of other cuts (tenderloin / drumstick) obtained in the current study, of no significant difference for CB-Slow and HB-Flex $(\mathrm{P}<0.05)$. Studying $\mathrm{CB}$ hybrid, the authors reported higher breast and sable production (34.20 and $16.20 \%$, respectively) than other pedigrees (Paraiso Pedres and Isa Label). However, the authors did not compare the data with the HB, but reported that the proportion of wing / leg / back was higher for the other lines studied, which was also observed in the present study [9]. However the cuts mentioned were not transected on meat and bone. The variations in yield cuts in hybrids, have been attributed to the growth rates and age at slaughtering as well as the fact that most of these hybrids (especially CB), are selected with a focus on yield breast. Using the Ross 308 strain Havenstein and Young et al [18, 19] found 15.2 and $20 \%$ yields of breast meat, in poultry slaughtered at 43 and 44 days, respectively. In contrary to the reported above, when they are compared to other lineages (Arbor Acres and Ross), some variations have been reported. Mendes [10] by comparing HB with Arbor Acres, found that the second hybrid showed the highest percentage of leg meat $(\mathrm{P}<0.05)$ to HB (better feed conversion). Vieira [13], comparing breast yield (CB and Ross), stated that the hybrid Ross showed the highest yield for breast meat (31 days of age) than the $\mathrm{CB}$, which obtained best results for thigh and drumstick (using different diets with protein profiles). Authors such as Stringhini and Boldorini et al [11, 15] did not observe significant differences between the two lineages. Comparing the broiler (male) meat yield and weight [20] found in CB and HB lineages yields of breast with bone of 20.43 and 19.51 and values in drumstick yield of 10.63 to 10.51 , respectively.

(B) TOTAL: the 2 hybrids whole weight averages before and after slaughtering (carcasses yield) were 2665.10 \& $2566.38 \mathrm{~g}$ and $73.69 \& 73.49 \%$, respectively [21]. These data, were reported also by Winkelstroter [14] for the CB (84.69 and $84.49 \%$ ) and HB (3024 and $3129 \mathrm{~g}$ ) hybrids as a middle weight. In diets with levels of $3000 \mathrm{kcal} / \mathrm{kg}$. Meza et al [22] found $\mathrm{CB}$ carcass yield of $73.17 \%$. The $\mathrm{HB}$ lineage according to Barbosa et al [23] presented $82.71 \%$ yield at 49 days of age.

\section{Conclusions}

The results obtained allow to infer that there was a significant difference between the two hybrids (CB-Slow and HB-Flex) tested characteristics, both for cuts weight and yield. The CB-Slow showed to be better on weight and yield of breast meat. The HB-Flex offers best results for wing and thigh. Important to emphasize the need for more detailed information about the hybrids (CB, CB-Fast and specific CB-Slow) when reported in the literature, as nuances of each lineage can make a difference in the final cuts data obtained in a study.

\section{REFERENCES}

[1] Fernandes, C. M., Paz, G, and Lins, J, (2008). Avaliação das condições de frigorificação de carcaças de frangos de corte em diferentes pontos do processo produtivo, distribuição e comercialização. Universidade Castelo Branco.

[2] Abdullah, F. A. A., \& Buchtová, H. (2015). The quality of different types of chicken breast meat (organic, conventional, tenderized). FOLIA, 59(3):173-178.

[3] Moreira, J., Mendes, A. A., Garcia, E. A., Oliveira, R. P. D., Garcia, R. G., and Almeida, I.C.L.D. (2003). Avaliação de desempenho, rendimento de carcaça e qualidade da carne do peito em frangos de linhagens de conformação versus convencionais. Rev. Bras. Zootecnia, 32(6): 1663-1673.

[4] Nilton, O and Rubison, R. A. Cortes e Rendimento, 1 ed., $\mathrm{O}$ mundo do frango. Ed. do Autor, Criciúma. 2006 281-285.

[5] Sui, Z., Raubenheimer, D., Cunningham, J., and Rangan, A. (2016). Changes in Meat/Poultry/Fish Consumption in Australia: From 1995 to 2011-2012. Nutrients, 8(12): 753.

[6] Castillo, C.J.C. (2001). Qualidade de carcaça e carne de aves. In: Congresso Brasileiro de Ciência e Tecnologia de Carnes, São Pedro. 
[7] Smyth, A. B., O’Neill E., Smith, D. M., Richardson, R. I., and Mead, G. C.1999. Functional properties of muscle proteins in processed poultry products: In Poult. Meat Sci. Poult. Sci. Symp. Series, Wallingford, UK CABI Publishing, 25: 377 $-396$.

[8] Ripoll, G., Alberti, P., and Panea, B. 2015. Consumer segmentation based on food-related lifestyles and perception of chicken breast. Int. Jour. of Poul. Sci, 14(5): 262.

[9] dos Santos, A. C. R., Pereira, L. A., and Gonçalves, C. A. A. 2011. Investigação de Fatores que Afetam a Qualidade e o Rendimento de Carcaças de Frango. Norte Científico, 5(1).

[10] Mendes, A. A., Garcia, E. A, and Patricio, I. S, 1988. Desempenho e rendimento de carcaça de cinco linhagens comerciais de frangos de corte. Bol. Tec. Big Birds, (1):1-10.

[11] Stringhini, J. H., Laboissiére, M., Muramatsu, K., Leandro, N. S. M., and Café, M. B. 2003. Avaliação do desempenho e rendimento de carcaça de quatro linhagens de frangos de corte criadas em Goiás. Rev. Braz. Zootechny, 32(1): 183-190.

[12] Flemming, J. S., Janzen, A. S, and Endo, M. A, 1999. Rendimento de carcaça em linhagens comerciais de frangos de corte. Arch. Vet. Sci, 4: 61-63.

[13] Vieira, S.L.1999. Considerações sobre as características de qualidade da carne de frango e fatores que podem afetá-lo.In: XV Simpósio Brasil Sul de Avicultura e VI Brasil Sul Poultry Fair: 61 .

[14] Winkelstroter, L. K., Smith, M.T.P., and da Silva, L.C. (2012). Rendimento de Carcaça e Cortes de Frangos de corte, alimentados com diferentes níveis nutricionais no período de 1 a 49 dias de idade. In: IX Simpósio Brasileiro de Melhoramento Animal, João Pessoa.

[15] Boldorini, C. C., Fernandes, E. A., Silveira, M. M., Marcacine, B. A, 2012. Estudo comparativo entre diferentes linhagens comercias de frangos de corte. Rev. Bras. Ciên. Avic. 32.
[16] MAPA - Ministry of Agriculture, Livestock and Supply. Agriculture Defense Department. Ordinance 210, 10/Nov/1998. Technical Regulation for poultry hygienic and sanitary inspection. Official Gazette, Executive Branch, Brasilia, DF 26 November 1998 Annex IV: 34.

[17] ABPA. Brazilian Association of Animal Protein Annual Report 2015. Available: $<$ http://abpa-br.com.br/files/Relatori oAnual_UBABEF_2015_DIGITAL.pdf.

[18] Havenstein, G. B., Ferket, P. R., and Qureshi, M. A. 2003. Carcass composition and yield of 1957 versus 2001 broilers when fed representative 1957 and 2001 broiler diets. Poult. Sci, 82(10):1509-1518.

[19] Young, L. L., Northcutt, J. K., Buhr, R. J., Lyon, C. E., and Ware, G. O. 2001. Effects of age, sex, and duration of postmortem aging on percentage yield of parts from broiler chicken carcasses. Poult. Sci, 80(3): 376-379.

[20] Nikolova, N. \& Pavlovski, Z. 2009. Major carcass parts of broiler chicken from different genotype, sex, age and nutrition system. Biotechnology in animal husbandry, 25(5-6-2): 1045-1054.

[21] Soares, C.E; Dahlke, F.; Scussel, VM. 2016. Evaluation on weight and yield chicken cuts: hibrids Cobb 500 Slow and Hubbard Flex. Journal of Processing and Technology (suppl.) $7: 69$.

[22] Meza, S. K. L., Nunes, R. V. Tsutsumi, C. Y., Vieites, F. M., Scherer, C., Henz, J.R, and Bayerle, D.F, 2015. Níveis de energia metabolizável e lisina digestível sobre a composição e rendimento de carcaça de frangos de corte. Semina: Ciências Agrárias, 36(2): 1079-1089.

[23] Barbosa, F. J. V., Lopes, J. B,. Figueiredo, A. V,. Abreu, M. L. T. D,. Dourado, L. R. B,. Farias, L. A, and Pires, J. E. P. 2008. Níveis de energia metabolizável em rações para frangos de corte mantidos em ambiente de alta temperatura. Ver. Bras. de Zootechny, 849-855. 